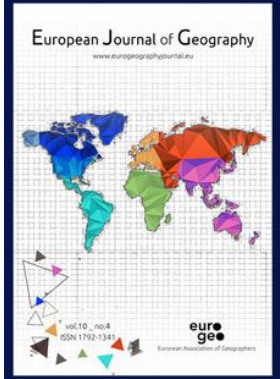

European Journal of Geography

Volume 11, Issue 2, pp. 033 - 046

Article Info:

Received: 03/09/2020; Accepted: 12/12/2020

Corresponding Author: * molnarvandaeva@science.unideb.hu https://doi.org/10.48088/10.48088/ejg.v.mol.11.1.33.46

\title{
Species-level classification of urban trees from worlduiew-2 imagery in Debrecen, Hungary: an effective tool for planning a comprehensive green network to reduce dust pollution
}

\author{
Vanda É. MOLNÁR ${ }^{1^{*}}$, Edina SIMON ${ }^{\text {** }}$, Szilárd SZABÓ ${ }^{1}$
}

${ }^{1}$ University of Debrecen, Hungary

Keywords:

hidden geographies, remote sensing, multispectral

image,

maximum

likelihood,

support vector

machine

\begin{abstract}
Urban green spaces of cities are crucial elements of city structure that ensure habitat for species and ecological functionality of habitat patches, maintain biodiversity, and provide environmental services. However, detailed maps intended for planning and improuing the existing network require a quick and effective technique for assessing the possibilities. Multispectral imagery is an accessible source for species-level classification of urban trees. Using a multispectral image from the WorldView-2 satellite sensor, we classified six of the most common urban tree species in Debrecen, Hungary. Maximum Likelihood (ML) and Support Vector Machine (SVM) classifiers were applied to different numbers of the MNF-transformed bands. The best overall accuracy was achieved with the ML algorithm applied to the first four transformed bands (75.1\%), and with the SVM algorithm applied to eight bands $(71.0 \%)$. In general, $\mathrm{ML}$ performed better than SVM. Despite the relatively low number of spectral bands, we achieved moderately good accuracy for basic vegetation mapping, which can be used in spatial planning and decision making. In a future interdisciplinary research study, we could merge the classification results with the dust adsorption capacity of individual species to assess the reduction of dust pollution by urban trees.
\end{abstract}

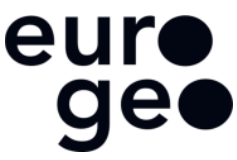

(c) Association of European Geographers
The publication of the European Journal of Geography (EJG) is based on the European Association of Geographers' goal to make European Geography a worldwide reference and standard. Thus, the scope of the EJG is to publish original and innovative papers that will substantially improve, in a theoretical, conceptual or empirical way the quality of research, learning, teaching and applying geography, as well as in promoting the significance of geography as a discipline. Submissions are encouraged to have a European dimension. The European Journal of Geography is a peer-reviewed open access journal and is published quarterly. 


\section{INTRODUCTION}

Information on tree species composition is of great importance for the management of urban trees, from simple monitoring to the associated costs and benefits. The creation and maintenance of a green network in the urban fabric is also a primary tool of sustainable development (Mougiakou and Photis, 2014; Tulisi, 2017; Kertész and Křeček, 2019). Urban trees bring economic, psychological, recreational and aesthetic benefits, as well as mitigate climatic stress and urban heat islands (Wu and Zhang, 2008; Savić et al., 2013; Milošević et al., 2016; Cugnon et al., 2019), reduce air pollutants, and improve air quality (Yang et al., 2015; Hofman et al., 2016; Molnár et al., 2018, 2020). As their role is irreplaceable, we need to pay particular attention to their assessment. Moreover, the mapping of tree species that produce potentially allergenic pollen may prove beneficial as well (Brabant et al., 2019). Apart from biodiversity and tree health assessment, hazard and stress management, and monitoring of invasive species are also common research objectives (Fassnacht et al., 2016; Hüse et al., 2016). Our knowledge must be kept up to date due to rapid environmental changes. Pretzsch et al. (2017), for example, found that healthy urban trees accelerated their growth rate in the last decades due to climatic changes.

Tree leaves can efficiently adsorb air pollutants, especially dust, in stomatal openings and on waxy cuticles (Gajbhiye et al., 2019). Consequently, urban trees have been commonly used for indirect monitoring of dust pollution. Several studies can be found on the relation between particulate air pollution and the urban vegetation. Hofman et al. (2016) evaluated the effect of tree crown representation on atmospheric modelling of PM distribution. Gómez-Moreno et al. (2019) observed the ability of vegetation to reduce particulate matter emitted from a pollution hotspot. Furthermore, $\mathrm{Xu}$ et al. (2020) suggested that the details on particulate matter wash-off from tree leaves should be investigated as well.

Fixed air quality monitoring stations measure certain pollutants; however, deposited dust is rarely monitored at these stations. There is a standard dust-trapping method, which is considered to be the most reliable (MSZ 21454-1:1983), but the deployment of dust traps is spatially limited and requires suitable equipment and prior planning. Moreover, the deployed traps are exposed to theft and vandalism (Szabó et al., 2008). In contrast, the use of trees for dust monitoring can be advantageous due to their widespread distribution and very cost-effective sampling and analysis. Dust adsorbing properties of certain tree species have already been studied in Debrecen (Simon et al., 2014).

Remote sensing techniques are nowadays widely used for urban vegetation mapping. Multispectral remote sensing is an effective and accessible tool to create thematic maps that are useful in urban management or spatial planning (Burai et al., 2015a). Satellite images are available to survey vegetation types and species-level distribution even in areas with limited accessibility. Remote sensing techniques are much less time-consuming and laborious than extensive field surveys. However, as multispectral images include a relatively small number of spectral bands, the separation of tree species is often challenging, even at high spatial resolution, which is also important for species-level classification (Burai et al., 2019). On the other hand, space-borne data are still more cost-effective than hyperspectral aerial surveys, which usually cover only small areas (Deák et al., 2017). Despite the technologies available 
today, mapping and classifying individual tree species in urban areas is still a challenge due to the complex spatial structures and diverse species composition. This is particularly true for European cities, where compact structures are traditionally based in dense historical cores (González, 2017).

WorldView-2, an Earth observation satellite owned by DigitalGlobe, has been providing high-resolution images since 2009. Apart from the four traditional, standard bands (blue, green, red and NIR1), the additional bands (coastal blue, yellow, red-edge and NIR2) increase the possibility of species-level classification, as each band is representative of different biochemical parameters of plants. For example, the blue and red bands hold information about chlorophyll absorption, the red-edge band provides information on plant health, while the additional near-infrared band allows more information about vegetation water content and overall structure (Cross et al., 2019). In earlier studies, in order to achieve higher performance, multispectral data from WorldView-2 were often combined with airborne laser scanning (LiDAR) data to classify tree species in either urban forests (Verlič et al., 2014) or urban parks (Hartling et al., 2019). The accuracy of species classification based on multispectral data alone is rarely tested. However, considering the possible application of the classification results, methods using only multispectral data and having lower accuracies might be sufficient. Our aim was to provide further information on the possibilities of using satellite data for species identification.

In an interdisciplinary research study, we could combine remote sensing methods with other disciplines in order to expand our knowledge of natural processes. For example, we could merge data on the composition of urban tree species and species classification obtained through remote sensing with data on dust adsorption capacity of individual species, so that we could provide an estimate of the reduction of dust pollution-natural or anthropogenic-by urban trees for a specific city. The dust adsorption capacity and tolerance to air pollution is different for each species (Simon et al., 2014; Molnár et al., 2020). We will have to expand our analysis of dust adsorption capacity to other tree species, especially to those that have a high number of individuals in their urban population and can be identified via remote sensing. Furthermore, reliable methods need to be developed for estimating the leaf surface area that actively participates in dust adsorption for the studied species. In summary, if we have access to species-specific dust adsorption capacity, active leaf surface area, and a species distribution map, we can estimate the amount of deposited dust that is filtered from the air in urban areas.

In the present study, we applied supervised, pixel-based classification methods to multispectral imagery from the WorldView-2 satellite sensor to classify urban tree species in Debrecen, Hungary. Our aim was to classify the image for tree species using from two to eight MNF-transformed bands to achieve the highest possible accuracy and to determine the applicability of multispectral data for species-level classification of trees in an urban environment. 


\section{MATERIALS AND METHODS}

Our study was conducted in Debrecen, Hungary, which is the second largest city in the country with 203,000 inhabitants. It is one of the most important cultural centres in Hungary as well as the regional centre of the Northern Great Plain (Lóki, 2020). The land to the west of the city is an intensive agricultural production area, and the prevailing wind is also westerly. Therefore, the distribution of green infrastructure would be desirable to prevent the dust-laden air masses from entering the inner areas of the city. Our study area of $0.7 \mathrm{~km}^{2}$ included part of the main campus of the University of Debrecen and nearby residential areas (Figure 1). The chosen area is representative for the distribution of the dominant tree species in Debrecen.
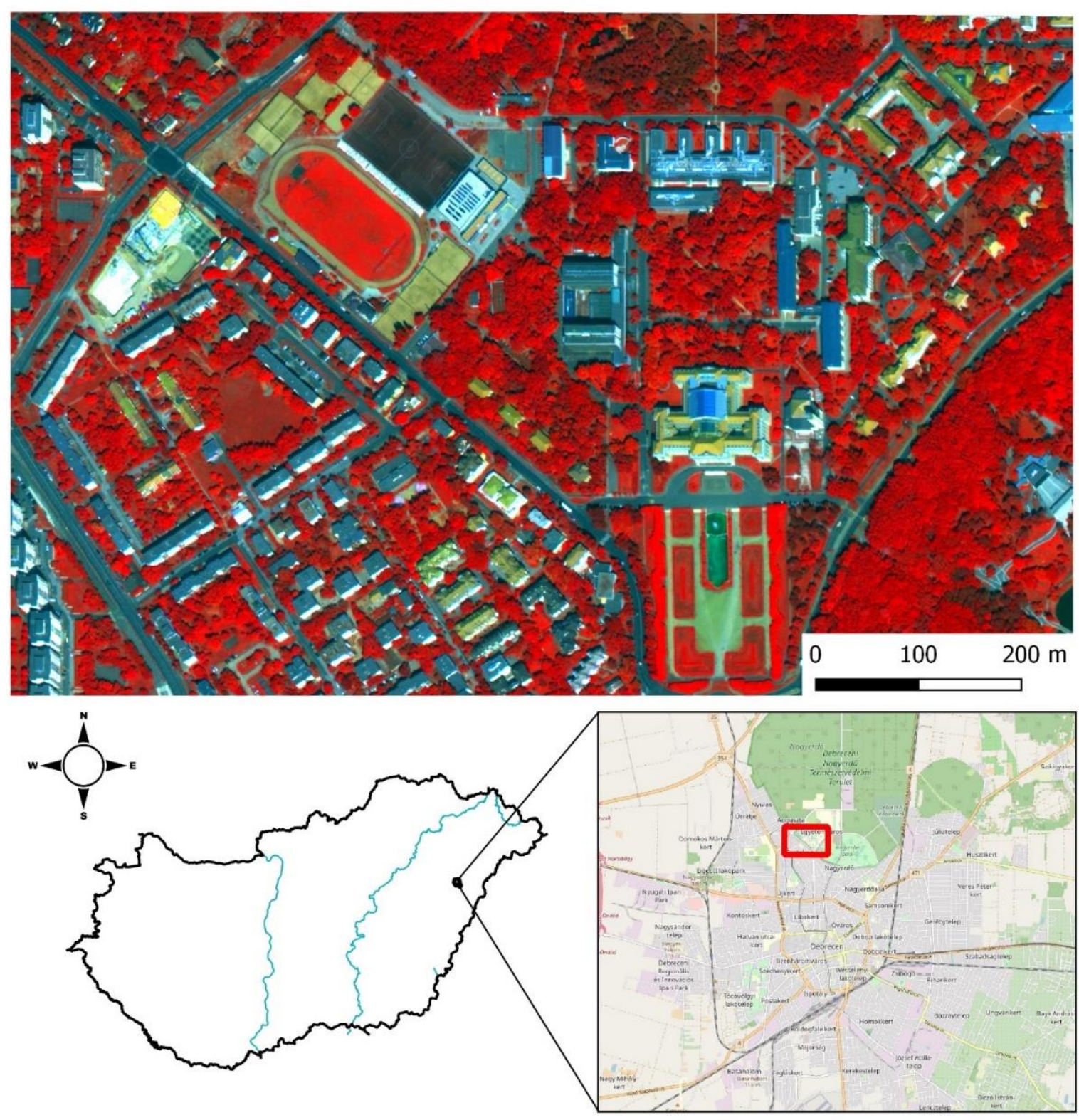

Figure 1. Location of the study area in Debrecen, Hungary / False colour composite of the NIR2 (R), yellow $(G)$ and coastal $(B)$ bands from the WorldView-2 image 
We used a WorldView-2 satellite image for the classification. The image was captured with no cloud cover in mid-summer, on $24^{\text {th }}$ July 2016, to auoid spectral differences caused by different vegetation stages. The image consisted of eight multispectral bands between 400 and $1040 \mathrm{~nm}$ with a $2 \mathrm{~m}$ geometric resolution and a $0.5 \mathrm{~m}$ resolution panchromatic band $(450-800 \mathrm{~nm})$. We applied pan-sharpening to the image using the Gram-Schmidt method in the software ENVI/IDL 5.3 (Maurer, 2013; Li et al., 2017). By fusing the panchromatic band with the multispectral bands, we enhanced the geometric resolution of the multispectral bands to $0.5 \mathrm{~m}$.

We studied six of the most common tree species in the area: Norway maple (Acer platanoides), silver maple (Acer saccharinum), common lime (Tilia $x$ europaea), American sycamore (Platanus occidentalis), black locust (Robinia pseudoacacia) and conifers (Pinaceae and Thuja). The last category, referred to as the 'conifers', included several coniferous tree species, which are hereafter treated as one group. The Norway maple and the common lime are native, while the silver maple, the American sycamore and the black locust are outside their native range in Hungary; the latter can even be considered invasive (Vítkouá et al., 2017). These species are commonly found in urban areas and along roads.

Field reference data were collected from the six species in the study area $(n=563)$. We selected individual healthy trees that could be easily distinguished and identified on the image. The data were randomly divided into train (70\%) and test (30\%) subsets, which were used to train the classifying algorithms and then test their accuracy by creating confusion matrices. The Minimum Noise Fraction (MNF) transformation was used to segregate noise in the data. The MNF transform is a linear transformation that consists of two consecutive principal components analysis rotations (Burai et al., 2010, 2015b). Then the Maximum Likelihood (ML) and Support Vector Machine (SVM) classifiers were applied to different numbers of the MNF-transformed bands to find the optimal number of features. ML, an efficient parametric classifier that uses a probability theorem to discriminate pixels into classes, performed well in several studies (Szabó et al., 2014). However, it assumes normal distribution of the training data and is sensitive to outliers, which could lead to errors in training data collection, for example, including non-representative data or involving adjacent pixels belonging to other land cover classes (Otukei and Blaschke, 2010). SVM is a non-parametric robust classifier that uses so-called hyperplanes in the multidimensional space defined by the image bands and can also handle non-linear data and outliers. Several researches proved its efficiency in different scientific fields (Gautam et al., 2008; Turker and KocSan, 2015; Yeganeh et al., 2017; Balázs et al. 2018). Both of these methods are commonly used for image classification as they perform well in comparison with other methods.

Accuracy assessment was carried out after the classification by calculating the overall accuracy, the kappa coefficient, the producer's accuracy and the user's accuracy using the test pixels (Abriha et al., 2018; Congalton, 2001). The overall accuracy refers to the proportion of pixels that were classified correctly. The kappa coefficient tests how far the classification is from being random. The producer's accuracy is closely related to the omission error, as it represents how well a category of reference pixels was classified. The user's accuracy, on the other hand, is a complement of the commission error; it indicates how often a classified pixel represents the actual category in which it was classified (Congalton, 2001; Foody, 2002). 


\section{RESULTS AND DISCUSSION}

We classified urban tree species with a straightforward approach using pixel-based algorithms. The ML and SVM classifiers were applied to different numbers of the MNFtransformed bands, from two to eight. The overall accuracy varied significantly depending on the number of bands included in the classifications (Figure 2). The overall accuracy percentages ranged between $52.66 \%$ and $75.15 \%$. The highest overall accuracy for ML was achieved with the first four transformed bands (overall accuracy $=75.15 \%$, kappa coefficient $=0.697$ ), while for SVM, all eight bands had to be included (overall accuracy $=71.01 \%$, kappa coefficient $=0.641)$. Comparing the two methods, $\mathrm{ML}$ generally performed better than SVM, since the overall accuracy was higher for the former in each respective pair of cases. Nitze et al. (2012) found that ML was the weakest of the five algorithms, although in our case it provided at least similar accuracies at the overall and class levels (also with respect to the user's accuracy and producer's accuracy). The reason may be better data distribution of the train classes and that we used a noise-reduced and normalized data as a training set. Szabó et al. (2014) and Varga et al. (2015) also found that ML can perform well or better than other algorithms. The lowest overall accuracy was achieved when using only the first two MNF bands in the case of both ML and SVM. This is evident since these two bands explain the least cumulative variance of the data. The percentage of accuracy did not show a monotonic change with the distance from the optimal number of bands.

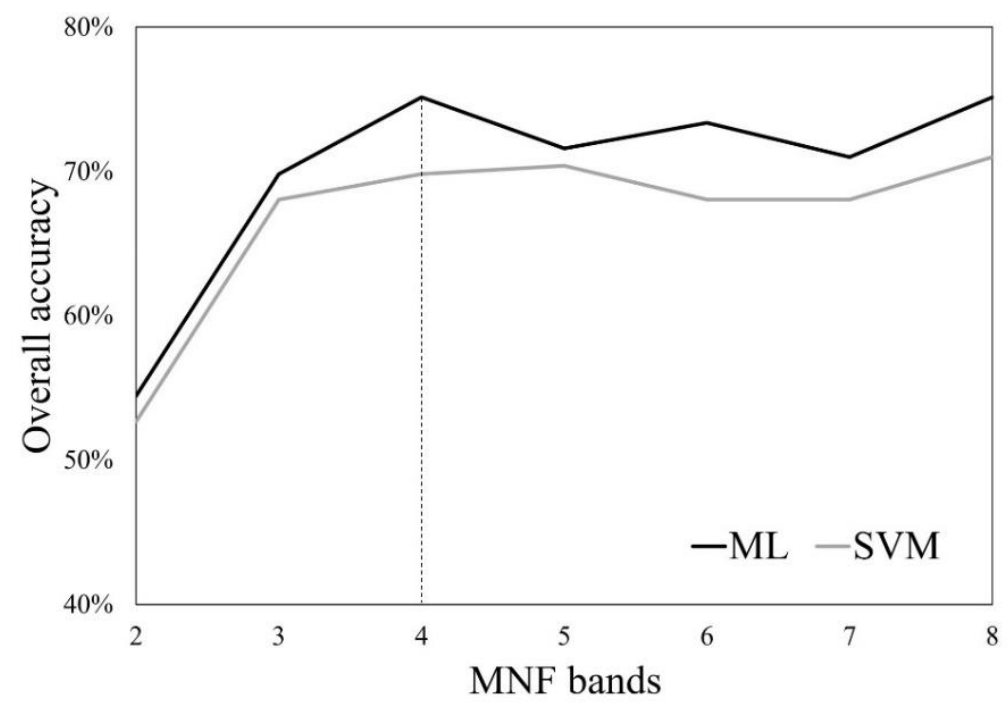

Figure 2. Overall accuracy of the ML and SVM classifications at different numbers of the MNF bands included

Further accuracy assessment was conducted for the cases of the highest overall accuracies (i.e. ML with the first four bands and SVM with eight bands included during the classification process). The producer's accuracy and the user's accuracy varied for the studied tree species (Table 1). The American sycamore and the conifers were separated with the highest accuracies both with ML and SVM, with the producer's accuracy ranging between $78.57 \%-89.29 \%$. Coniferous species are usually easily separated from deciduous species, since their spectral signature differs greatly in the 
red-edge and near infra-red bands (Verlič et al., 2014). Regarding the user's accuracy, the classification was the most reliable for the Norway maple and the conifers (81.08\%-92.00\%), which means that pixels classified as Norway maples or conifers were rarely a different species in reality. The biggest difference between the ML and SVM classifiers was in the case of the black locust, which was classified with the lowest accuracy using SVM (38.89\%), while ML performed far better, resulting in the $83.33 \%$ producer's accuracy. The common lime also showed a moderate variance between the methods. For this species, the producer's accuracy and the user's accuracy were fairly similar when using $\mathrm{ML}, 71.05 \%$ and $72.97 \%$ respectively. SVM, on the other hand, showed a wider range of accuracies, as the producer's accuracy exceeded $M L$, resulting

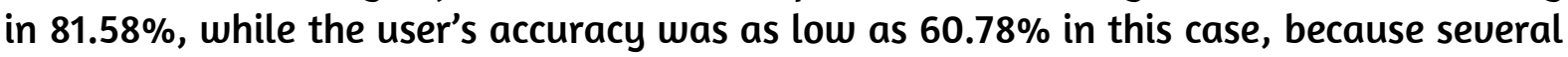
maple and black locust testing pixels were classified as the common lime. The weakest results were obtained for the silver maple, with the accuracy ranging between $40.00 \%-$ $64.29 \%$.

Table 1. The producer's accuracy (PA) and user's accuracy (UA) in the case of ML (the first four bands) and SVM (eight bands)

\begin{tabular}{|l|c|c|c|c|}
\hline \multirow{2}{*}{ Species } & \multicolumn{2}{|c|}{ ML } & \multicolumn{2}{c|}{ SVM } \\
\cline { 2 - 5 } & PA (\%) & UA (\%) & PA (\%) & UA (\%) \\
\hline Norway maple & 67.44 & 87.88 & 69.77 & 81.08 \\
\hline Silver maple & 64.29 & 42.86 & 42.86 & 40.00 \\
\hline Common lime & 71.05 & 72.97 & 81.58 & 60.78 \\
\hline American sycamore & 89.29 & 78.13 & 82.14 & 71.88 \\
\hline Black locust & 83.33 & 68.18 & 38.89 & 77.78 \\
\hline Conifers & 78.57 & 91.67 & 82.14 & 92.00 \\
\hline
\end{tabular}

Despite the relatively low number of spectral bands from the original image, we achieved moderately good accuracy for basic vegetation mapping of common urban trees in Debrecen using multispectral imagery. Evidently, further enhancements of classification accuracy can be made by expanding the reference dataset and testing other classifiers.

There are several studies that compare the classification performance and other potentials of multispectral and hyperspectral images (Govender et al., 2008; Burai et al., 2019; Lu et al., 2019), and although the use of more bands usually leads to higher accuracy, the cost of hyperspectral surveys is still much higher. It is therefore reasonable to improve the methods that use cost-effective data sources; Persson et al. (2018), for example, achieved good accuracy in tree species identification with freely available Sentinel-2 data. There is also a possibility that in unfortunate circumstances a large number of bands can provide more confusion than separability (Brabant et al., 2019).

There are inherent limitations in diverse urban environments. Even if we mask out artificial materials and surfaces using vegetation indices, species classification can still be problematic due to the background materials that are present in a pixel (Degerickx et al., 2018). The overlapping of foliage and grass, pavement and rooftops, as well as the intertwining of adjacent tree crowns must be considered when mapping urban trees (Launeau et al., 2017). 
Although all classifications contain errors, these maps can be used in urban planning to improve the interconnection between habitat patches and to contribute to the conservation of biodiversity. Built-in areas in a city represent an artificial environment and all green patches can be regarded as valuable spots. Even though these spots are sometimes degraded and species composition unfauourable due to invasive species and weeds, these patches can at least perform their ecological function in a network. In addition, Debrecen suffers from a high dust load. Its western surrounding areas are intensively farmed, and especially in spring, when the strongest winds are blowing, the dust concentration (PM10) is usually above the threshold of acceptable levels (100 $\left.\mathrm{g} / \mathrm{cm}^{3} ; \mathrm{VM}, 2011\right)$. The other sources of dust pollution are traffic, usually with increased heauy metal content (Ram et al., 2014; Jandacka et al., 2017; Budai and Clement, 2018), and as in all European countries, the Saharan dust (Borbély-Kiss et al., 1999, 2004; Varga et al., 2013; Varga and Roettig, 2018). Based on dust adsorption of tree leaves, it was found that trees also act as sediment traps for urban dust (Braun et al., 2007; Molnár et al., 2018; Varga et al., 2019) and are good indicators of dust pollution level due to physiological responses (Molnár et al., 2020). As tree species adsorb dust in their leaves differently, according to the different number of leaves and the roughness of their surface (Simon et al., 2014), mapping the tree species composition can help in the selection of appropriate species in the planning of urban green infrastructure. Extending our research to the city level and combining it with the information on the dust adsorption capacity of different tree species can provide a valuable input for decision makers.

\section{CONCLUSIONS AND HIDDEN POTENTIALS}

This study aimed to assess the ability of multispectral WorldView-2 imagery to classify tree species in an urban environment. Six common roadside tree species were included in this study. The overall accuracy of the best classification was $75 \%$, which offers an opportunity to provide a rough estimation of the species distribution in a city. Our research highlighted the potential of remotely sensed data to assist in easy and quick mapping of tree species in urban areas. It can also serve as a tool for expanding our knowledge on the benefits of urban green spaces. This includes ecological functions, such as providing habitat and refuge, and environmental functions, which are often referred to as ecosystem services, such as microclimate regulation, rainwater drainage, reducing particulate and gaseous pollutants, and moderating wind speed and noise.

We would also like to draw attention to the hidden opportunities that a map of tree species distribution in an urban environment presents. We intend to integrate the classification results into environmental research questions from other disciplines. Specifically, by merging the species distribution with data on dust adsorption capacity of individual species, it would be possible to estimate the extent of dust reduction by trees in a city. To do so, we need to adopt an interdisciplinary approach to the problem, using GIS and ecology methods. The mapping and classification of individual trees on a larger scale by remote sensing is still hindered by overlaps in the canopy structures and the spectral variability of individual species. However, dust capturing capacity, which is specific to every tree species, can be determined through direct sampling and measuring. Urban dust pollution is a topical issue for most large cities, and a fine example of the importance of integrating all potential methods and data sources to find the best solutions. 


\section{ACKNOWLEDGEMENTS}

The research was funded by the TNN123457 and KH126481 projects.

\section{REFERENCES}

Abriha, D., Kouács, Z., Ninsawat, S., Bertalan, L., Bertalan-Balazs, B., and Szabo, S. (2018). Identification of roofing materials with Discriminant Function Analysis and Random Forest classifiers on pan-sharpened WorldView-2 imagery - a comparison. Hungarian Geographical Bulletin: 67: 375-392. doi:10.15201/hungeobull.67.4.6.

Balázs, B., Bíró, T., Dyke, G., Singh, S., and Szabo, S. (2018). Extracting water-related features using reflectance data and principal component analysis of Landsat images. Hydrological Sciences Journal: 63(2): 269--284. doi: 10.1080/02626667.2018.1425802.

Borbély-Kiss, I., Kiss, Á. Z., Koltay, E., Szabó, G., and Bozó, L. (2004). Sahara dust episodes in Hungarian aerosol: elemental signatures and transport trajectories. SCI Journal of Aerosol Science: 35: 1205-1224.

Borbély-Kiss, I., Koltay, E., Szabó, G., Bozó, L., and Tar, K. (1999). Composition and sources of urban and rural atmospheric aerosol in Eastern Hungary. J Aerosol Sci: 30: 369-391.

Brabant, C., Aluarez-Vanhard, E., Laribi, A., Morin, G., Nguyen, K. T., Thomas, A., and Houet. T. (2019). Comparison of Hyperspectral Techniques for Urban Tree Diversity Classification. Remote Sensing: 11(11): 1269. doi:10.3390/rs11111269.

Braun, M., Margitai, Z., Tóth, A., and Leermakers, M. (2007). Environmental monitoring using linden tree leaves as natural traps of atmospheric deposition: a pilot study in Transiluania, Romania. Acta Geographica Debrecina Landscape \& Environment: 1(1): 24-35. Auailable at from https://ojs.lib.unideb.hu/landsenv/article/view/2209 (Accessed 10 April 2020).

Budai, P., and Clement, A. (2018). Spatial distribution patterns of four traffic-emitted heauy metals in urban road dust and the resuspension of brake-emitted particles: Findings of a field study. Transportation Research Part D: Transport and Environment 62: 179-185. https://doi.org/10.1016/j.trd.2018.02.014.

Burai, P., Beko, L., Lenart, C., Tomor, T., and Kovacs, Z. (2019). Individual Tree Species Classification Using Airborne Hyperspectral Imagery and Lidar Data. 10th Workshop on Hyperspectral Imaging and Signal Processing: Euolution in Remote Sensing (WHISPERS), Amsterdam, Netherlands, pp. 1-4.

Burai, P., Deák, B., Valkó, O., and Tomor, T. (2015b). Classification of Herbaceous Vegetation Using Airborne Hyperspectral Imagery. Remote Sensing: 7: 2046-2066. Auailable at https://doi.org/10.3390/rs70202046 (Accessed 10 April 2020).

Burai, P., Lövei, G., Lénárt, C., Nagy, I., and Enyedi, E. (2010). Mapping aquatic vegetation of the Rakamaz-Tiszanagyfalui Nagy-Morotua using hyperspectral imagery. Acta Geographica Debrecina Landscape \& Environment: 4(1): 1-10. Available at https://ojs.lib.unideb.hu/landsenv/article/view/2268 (Accessed 10 April 2020). 
Burai, P., Tomor, T., Bekő, L., and Deák, B. (2015a). Airborne hyperspectral remote sensing for identification grassland vegetation. International Society for Photogrammetry and Remote Sensing, Spatial Inf. Sci. XL-3/W3: 427-431. Auailable at https://doi.org/10.5194/isprsarchives-XL-3-W3-427-2015 (Accessed 10 April 2020).

Congalton, R. (2001). Accuracy assessment and validation of remotely sensed and other spatial information. International Journal of Wildland Fire: 10(4): 321-328. doi: 10.1071/WF01031.

Cross, M., Scambos, T., Pacifici, F., Vargas-Ramirez, O., Moreno-Sanchez, R., and Marshall, W. (2019). Classification of Tropical Forest Tree Species Using Meter-Scale Image Data. Remote Sensing: 11: 1411. Auailable at https://doi.org/10.3390/rs11121411 (Accessed 10 April 2020).

Cugnon, G., Caluwaerts, S., Duchêne, F., Hamdi, R., Termonia, P., Top, S., Vergauwen, T., and van Schaeybroeck, B. (2019). Climate sensitivity to land use changes over the city of Brussels. Geographica Pannonica: 23(4): 269-276. doi:10.5937/gp2324214.

Deák, M., Telbisz, T., Áruai, M., Mari, L., Horuáth, F., Kohán, B., Szabó, O. and Kouács, J. (2017). Heterogeneous forest classification by creating mixed vegetation classes using E0-1 Hyperion. International Journal of Remote Sensing: 38(18): 5215-5231. Available at https://doi.org/10.1080/01431161.2017.1325529 (Accessed 10 April 2020).

Degerickx, J., Roberts, D.A., McFadden, J.P., Hermy, M., and Somers, B. (2018). Urban tree health assessment using airborne hyperspectral and LiDAR imagery. International Journal of Applied Earth Observation and Geoinformation: 73: 26-38. Auailable at https://doi.org/10.1016/j.jag.2018.05.021 (Accessed 10 April 2020).

Fassnacht, F., Latifi, H., Stereńczak, K., Lefsky, M., Straub, C., Waser, L., Ghosh, A., and Modzelewska, A. (2016). Review of studies on tree species classification from remotely sensed data. Remote Sensing of Environment: 186: 64-87. Auailable at http://dx.doi.org/10.1016/j.rse.2016.08.013 (Accessed 10 April 2020).

Foody, G. M. (2002). Status of land cover classification accuracy assessment. Remote Sensing of Environment: 80(1): 185-201. Auailable at https://doi.org/10.1016/S0034-4257(01)00295-4 (Accessed 10 April 2020).

Gajbhiye, T., Pandey, S. K., Lee, S. S., and Kim, K. H. (2019). Size fractionated phytomonitoring of airborne particulate matter (PM) and speciation of PM bound toxic metals pollution through Calotropis procera in an urban environment. Ecological Indicators: 104, 32-40. Auailable at https://doi.org/10.1016/j.ecolind.2019.04.072 (Accessed 10 April 2020).

Gautam, R. S., Singh, D., Mittal, A., and Sajin, P. (2008). Application of SVM on satellite images to detect hotspots in Jharia coal field region of India. Advances in Space Research: 41(11): 1784-1792. Auailable at https://doi.org/10.1016/j.asr.2007.05.011 (Accessed 10 April 2020).

Gómez-Moreno, F. J., Artíñano, B., Ramiro, E. D., Barreiro, M., Núñez, L., Coz, E., Dimitroulopoulou, C., Vardoulakis, S., Yagüe, C., Maqueda, G., Sastre, M., RománCascón, C., Santamaría, J. M., and Borge, R. (2019). Urban vegetation and particle 
air pollution: Experimental campaigns in a traffic hotspot. Environmental Pollution: 247: 195-205. doi: 10.1016/j.enupol.2019.01.016.

González, M. J. G. (2017). Planning, urban sprawl and spatial thinking. European Journal of Geography: 8(1): 32-43.

Govender, M., Chetty, K., Naiken, V., and Bulcock, H. (2008). A comparison of satellite hyperspectral and multispectral remote sensing imagery for improved classification and mapping of vegetation. Water SA.: 34(2). doi:10.4314/wsa.v34i2.183634.

Hartling, S., Sagan, V., Sidike, P., Maimaitijiang, M., and Carron, J. (2019). Urban Tree Species Classification Using a WorldView-2/3 and LiDAR Data Fusion Approach and Deep Learning. Sensors: 19(6): 1284. doi:10.3390/s19061284.

Hofman, J., Bartholomeus, H., Janssen, S., Calders, K., Wuyts, K., Van Wittenberghe, S., and Samson, R. (2016). Influence of tree crown characteristics on the local PM 10 distribution inside an urban street canyon in Antwerp (Belgium): A model and experimental approach. Urban Forestry \& Urban Greening: 20: 265-276. doi: 10.1016/j.ufug.2016.09.013.

Hüse, B., Szabó, S., Deák, B., and Tóthmérész, B. (2016). Mapping an ecological network of green habitat patches and their role in maintaining urban biodiversity in and around Debrecen city (Eastern Hungary). Land Use Policy: 57: 574-581. Auailable at https://doi.org/10.1016/j.landusepol.2016.06.026 (Accessed 10 April 2020).

Jandacka, D., Durcanska, D., and Bujdos, M. (2017). The contribution of road traffic to particulate matter and metals in air pollution in the vicinity of an urban road. Transportation Research Part D: Transport and Environment: 50: 397--408. Available at https://doi.org/10.1016/j.trd.2016.11.024 (Accessed 10 April 2020).

Kertész, Á. and Křeček, J. (2019). Landscape degradation in the world and in Hungary. Hungarian Geographical Bulletin 68(3): 201-221. Available at https://doi.org/10.15201/hungeobull.68.3.1 (Accessed 10 April 2020).

Launeau, P., Kassouk, Z., Debaine, F., Roy, R., Mestayer, P. G., Boulet, C., Rouaud, J-M., and Giraud, M. (2017). Airborne hyperspectral mapping of trees in an urban area. International Journal of Remote Sensing: 38(5): 1277-1311. Auailable at https://doi.org/10.1080/01431161.2017.1285080 (Accessed 10 April 2020).

Li, H., Jing, L., and Tang, Y. (2017). Assessment of Pansharpening Methods Applied to WorldView-2 Imagery Fusion. Sensors: 17(1): 89. Auailable at https://doi.org/10.3390/s17010089 (Accessed 10 April 2020).

Liu, L., Coops, N. C., Aven, N. W., and Pang, Y. (2017). Mapping urban tree species using integrated airborne hyperspectral and LiDAR remote sensing data. Remote Sensing of Environment: 200: 170-182. Auailable at https://doi.org/10.1016/j.rse.2017.08.010 (Accessed 10 April 2020).

Lóki, J. (2020). Debrecen természetföldrajza. Debreceni Szemle 1:3-25.

Lu, B., He, Y., and Dao, P. D. (2019). Comparing the Performance of Multispectral and Hyperspectral Images for Estimating Vegetation Properties. IEEE Journal of Selected Topics in Applied Earth Observations and Remote Sensing: 12(6): 1784-1797. doi: 10.1109/JSTARS.2019.2910558. 
Maurer, T. (2013). How to pan-sharpen images using the Gram-Schmidt pan-sharpen method - a recipe. International Archives of the Photogrammetry, Remote Sensing and Spatial Information Sciences XL-1/W1.

Milošeuić, D. D., Sauić, S. M., Markouić, V., Arsenouić, D., and Šećerou, I. (2016). Outdoor human thermal comfort in local climate zones of Noui Sad (Serbia) during heat wave period. Hungarian Geographical Bulletin: 65(2), 129-137. Auailable at https://doi.org/10.15201/hungeobull.65.2.4 (Accessed 10 April 2020).

Molnár, V. É., Simon, E., Tóthmérész, B., Ninsawat, S., and Szabó, S. (2020). Air pollution induced vegetation stress - The Air Pollution Tolerance Index as a quick tool for city health evaluation. Ecological Indicators: 113: 106234. Auailable at https://doi.org/10.1016/j.ecolind.2020.106234 (Accessed 10 August 2020).

Molnár, V. É., Tóthmérész, B., Szabó, S., and Simon, E. (2018). Urban tree leaves' chlorophyll-a content as a proxy of urbanization. Air Quality, Atmosphere \& Health: 11: 665-671. Auailable at https://doi.org/10.1007/s11869-018-0573-5 (Accessed 10 April 2020).

Mougiakou, E., and Photis, Y. N. (2014). Urban green space network eualuation and planning: optimizing accessibility based on connectivity and raster GIS analysis. European Journal of Geography: 5(4): 19-46.

MSZ 21454-1:1983. Testing of solid impurities in ambient air. Determination of settling dust mass. 13.040.20 Környezeti atmoszférák.

Nitze, I., Schulthess, U., and Asche, H. (2012). Comparison of machine learning algorithms random forest, artificial neural network and support vector machine to maximum likelihood for supervised crop type classification. Proceedings of the 4th GEOBIA, May 7-9, 2012 - Rio de Janeiro - Brazil. p.035.

Otukei, J. R. and Blaschke, T. (2010). Land cover change assessment using decision trees, support vector machines and maximum likelihood classification algorithms. International Journal of Applied Earth Observation and Geoinformation: 12(1): S27S31. Auailable at https://doi.org/10.1016/j.jag.2009.11.002 (Accessed 10 April 2020).

Persson, M., Lindberg, E., and Reese, H. (2018). Tree Species Classification with MultiTemporal Sentinel-2 Data. Remote Sensing: 10(11): 1794. doi:10.3390/rs10111794.

Pretzsch, H., Biber, P., Uhl, E., Dahlhausen, J., Schütze, G., Perkins, D., Rötzer, T., Caldentey, J., Koike, T., van Con, T., Chavanne, A., du Toit, B., Foster, K., and Lefer, B. (2017). Climate change accelerates growth of urban trees in metropolises worldwide. Scientific Reports: 7(1). doi:10.1038/s41598-017-14831-w.

Ram, S.S., Kumar, R.V., Chaudhuri, P., Chanda, S., Santra, S.C., Sudarshan, M., and Chakraborty A. (2014). Physico-chemical characterization of street dust and resuspended dust on plant canopies: An approach for finger printing the urban environment. Ecological Indicators: 36: 334-338. Auailable at https://doi.org/10.1016/j.ecolind.2013.08.010 (Accessed 10 April 2020).

Sauić, S., Unger, J., Gál, T., Milošević, D., and Popou, Z. (2013). Urban heat island research of Novi Sad (Serbia): A review. Geographica Pannonica: 17(1): 32-36. doi:10.5937/GeoPan1301032S.

Simon, E., Baranyai, E., Braun, M., Cserháti, C., Fábián, I., and Tóthmérész, B. (2014). Elemental concentrations in deposited dust on leaves along an urbanization 
gradient. Science of The Total Environment: 490: 514-520. Auailable at https://doi.org/10.1016/j.scitotenu.2014.05.028 (Accessed 10 April 2020).

Szabó, G., Braun, M., Koi, R., and Szabó, S. (2008). Enuironmental impacts of an opencast mine. Methods of Landscape Research, Dissertations Commission of Cultural Landscape: 8: 113-126.

Szabó, S., Burai, P., Kouács, Z., Szabó, G., Kerényi, A., Fazekas, I., Paládi, M., Buday, T., and Szabo, G. (2014). Testing algorithms for the identification of asbestos roofing based on hyperspectral data. Environmental Engineering and Management Journal: 143(11): 2875-2880. doi: 10.30638/eemj.2014.323.

Tulisi, A. (2017). Urban Green Network Design: Defining green network from an urban planning perspective. TeMA - Journal of Land Use, Mobility and Environment: 10(2): 179-192. Auailable at https://doi.org/10.6092/1970-9870/5156 (Accessed 10 April 2020).

Turker, M. and Koc-San, D. (2015). Building extraction from high-resolution optical spaceborne images using the integration of support vector machine (SVM) classification, Hough transformation and perceptual grouping. International Journal of Applied Earth Observation and Geoinformation: 34: 58-69. Auailable at https://doi.org/10.1016/j.jag.2014.06.016 (Accessed 10 April 2020).

Varga, G. and Roettig, C. B. (2018). Identification of Saharan dust particles in Pleistocene dune sand- paleosol sequences of Fuerteventura (Canary Islands). Hungarian Geographical Bull: 67: 121-141.

Varga, G., Kouács, J., and Újuári, G. (2013). Analysis of Saharan dust intrusions into the Carpathian Basin (Central Europe) over the period of 1979-2011. Global Planet Change: 100: 333-342.

Varga, K., Szabó, S., Szabó, G., Dévai, G., and Tóthmérész, B. (2014). Improved land cover mapping using aerial photographs and satellite images. Open Geosciences: 7(1). doi:10.1515/geo-2015-0002.

Varga, T., Barnucz, P., Major, I., Lisztes-Szabó, Z., Jull, A., László, E., Pénzes, J., and Molnár, M. (2019). Fossil Carbon Load in Urban Vegetation for Debrecen, Hungary. Radiocarbon: 61(5): 1199-1210. doi:10.1017/RDC.2019.81.

Verlič, A., Đurić, N., Kokalj, Ž., Marsetič, A., Simončič, P., and Oštir, K. (2014). Tree Species Classification using WorldView-2 Satellite Images and Laser Scanning Data in a natural Urban Forest. Sumarski List: 138(9-10): 477-488.

Vítkouá, M., Müllerouá, J., Sádlo, J., Pergl, J., and Pyšek, P. (2017). Black locust (Robinia pseudoacacia) beloved and despised: a story of an invasive tree in Central Europe. Forest ecology and management: 384: 287-302. Auailable at https://doi.org/10.1016/j.foreco.2016.10.057 (Accessed 10 April 2020).

VM (2011). 4/2011. (I. 14.) VM rendelet a levegőterheltségi szint határértékeiről és a helyhez kötött légszennyező pontforrások kibocsátási határértékeiről. Auailable at https://net.jogtar.hu/ (Accessed 10 April 2020).

$\mathrm{Wu}, \mathrm{P}$. and Zhang, X. (2008). Study on the distribution changes of urban heat island based on heat-greenness feature space. The International Archives of the Photogrammetry, Remote Sensing and Spatial Information Sciences Vol. XXXVII. Part B7. 
Xu, X., Xia, J., Gao, Y., and Zheng, W. (2019). Additional focus on particulate matter wash-off events from leaves is required: A review of studies of urban plants used to reduce airborne particulate matter pollution. Urban Forestry \& Urban Greening: 48: 126559. doi:10.1016/j.ufug.2019.126559.

Yang, J., Chang, Y., and Yan, P. (2015). Ranking the suitability of common urban tree species for controlling PM2.5 pollution. Atmospheric Pollution Research: 6: 267-277.

Yeganeh, B., Hewson, M. G., Clifford, S., Knibbs, L. D., and Morawska, L. (2017). A satellite-based model for estimating PM2.5 concentration in a sparsely populated environment using soft computing techniques. Environmental Modelling \& Software: 88: 84-92. Auailable at https://doi.org/10.1016/j.enusoft.2016.11.017 (Accessed 10 April 2020). 